\title{
Decentralization as a disincentive for transnational terror? An empirical test
}

\author{
Axel Dreher ${ }^{\mathrm{a}}$ \\ Justina A. V. Fischer ${ }^{\text {b }}$ \\ SSE/EFI Working Paper Series in Economics and Finance \\ No 686 \\ December 2007
}

\begin{abstract}
Using panel data for a maximum of 109 countries over the years 1976-2000, we empirically analyze the impact of decentralization on the occurrence of transnational terror. Taking account of the potential simultaneity between terror and decentralization, our results show that expenditure decentralization robustly reduces the number of terror events in a country, while political decentralization has no impact.
\end{abstract}

Keywords: Terrorism, Decentralization, Democracy

JEL-Codes: D74; H70; H40

${ }^{a}$ KOF Swiss Economic Institute, ETH Zurich, 8092 Zurich, Switzerland and CESifo, Germany, mail@axel-dreher.de.

b Stockholm School of Economics, Department of Economics, Sveavägen 65, 11383 Stockholm, Sweden, Justina.fischer@hhs.se. 


\section{Introduction}

Following the 9/11 attacks on the World Trade Center the latest, transnational terrorism became subject of intense research. Still, what determines the terrorists' choice of target is not yet fully understood. Previous research suggests that economic development, but also political institutions such as, e.g., countries' degree of democracy, electoral system or constraints to the central government are important, while - surprisingly - the effect of national wealth is rather ambiguous (Abadie 2006, Frey and Luechinger 2004, Li 2005, Li and Schaub 2004). ${ }^{1}$

In this paper, we propose an additional institutional determinant of transnational terror: a target country's degree of decentralized governance structure. According to the analysis in Bjørnskov, Dreher and Fischer (2007), decentralization increases individual well-being, while Frey, Luechinger and Stutzer (2007) show terrorism to substantially reduce well-being. Arguably, one channel by which decentralization can increase societal welfare might thus be its impact on terrorism. Indeed, Frey and Luechinger (2004) argue that decentralized countries are politically and administratively more stable than more centralized states and, consequently, are less affected by terrorist attacks - as terrorists perceive the 'benefits' of their activities to decrease with the degree of decentralization. In addition, Li (2005) argues that increased political efficiency leads to less dissatisfaction and more political involvement of the population so that terror groups will be less successful in recruiting (dissatisfied) local residents as new members. As a consequence, less terrorist activities should occur in more decentralized countries.

However, the beneficial impact of decentralization on terror prevention is not as obvious as it might look at first sight. The traditional public finance literature suggests that decentralization may harm the production of public goods such as public safety. For example, decentralization may create coordination problems, lead to an underprovision and underfinancing of public safety, less policy innovation (Rose-Ackerman 1980, Strumpf 2002), and cause understaffing of security forces and other inefficiencies in fighting terrorism. In consequence, decentralization may make countries more vulnerable to terrorist attacks, as the marginal costs of committing terror are reduced, and we should expect terrorism to be more frequent in such decentralized countries.

The theoretical arguments underlying our analysis are derived from Frey and Luechinger (2004) and Li (2005). Surprisingly, the hypothesized effects of decentralization on terror have not yet been empirically tested. This omission is most likely due to the lack of

\footnotetext{
${ }^{1}$ Regarding the determinants of terror in the terrorist's countries of origin see Freytag, Krüger and Schneider (2006).
} 
adequate data on terrorism and political decentralization until most recently. Clearly, answering the question whether decentralization deters or attracts terrorists bears important policy implications. Answering this question is exactly the aim of this paper.

Specifically, this paper fills the gap in the literature by testing empirically whether and to what extent decentralization reduces or promotes transnational terror, based on a panel of 109 countries over the period 1976-2000. To anticipate our results, we find that fiscal decentralization reduces the occurrence of transnational terrorist events, while political autonomy does not affect terror.

The paper is organized as follows. The next section derives our hypotheses. Section 3 describes our measures of terrorism and decentralization, while the method of estimation is outlined in section 4 . The fifth section presents the results and the final section concludes.

\section{Hypotheses}

We base our hypotheses on the effect of decentralization on transnational terror on two main and rather independent arguments. The first relates to the willingness of local residents to support transnational terrorist groups and execute their plans. Such willingness arguably depends on the degree to which local policy outcomes are in line with citizens' preferences. Our second argument relates to the stability of the target country's polity, and how it may be affected by terror.

Turning to the first argument, according to Frey and Stutzer (2000), Li (2005), Bjørnskov, Dreher and Fischer (2007), and Dorn et al. (2007) the lack of opportunities to effectively participate in political decision-making induces political grievances and dissatisfaction with the process and the policy outcomes in the resident population. Building on this idea, Li (2005) argues that as democratic political systems increase political efficacy, transnational terror groups will be less successful in recruiting discontent or politically marginalized local residents as supporters. In a similar vein, decentralization of the politicoadministrative system arguably makes governments more honest and efficient, as it brings officials closer to the people. The economic theory of bureaucracy and the literature on institutional competition demonstrate that competition among public agencies reduces bureaucratic waste (e.g., Niskanen 1971), improves respect for regional differences in preferences (Tiebout 1961), serves as a discovery procedure (Hayek 1968), strengthens democratic control ("voice") and protects local minorities by facilitating "exit" (Hirschman 1970). Decentralization forces politicians to compete, leading to the improvement of local democracy and political accountability (Betz 1996). Decentralization thus permits dissenting 
residents to escape local policies they do not agree to by moving to a different jurisdiction in a Tiebout fashion, reducing the likelihood of becoming member of a terror group induced by their discontent. Clearly, with heterogeneous preferences in the population, not only political, but equally spending decentralization is likely to reduce terror.

Frey and Luechinger (2004) provide additional arguments. According to their analysis, one of the immediate main goals pursued by terrorists is to destabilize the polity of their target country. ${ }^{2}$ As Frey and Luechinger argue, "when the government loses power, and more importantly, when the political system's legitimacy is eroded, the terrorists' chances of achieving their goal improve" (ibidem, p.511). Thus, a governance structure that stabilizes the polity in a functional-systemic sense should decrease the marginal benefits of terrorist acts in a terrorists' cost-benefit analysis, reducing the levels of terrorist activities. Linking their argument to decentralization, the authors argue that "a polity with many different centers of decision-making and implementation is difficult, if not impossible, to destabilize" (ibidem, p.512).

For illustration, think of a biological entity that is composed of a multitude of cells expanding in all three dimensions. In such multi-cell entity, the destruction of one cell does not endanger the entity as a whole, as the remaining cells can take over the functions of the dysfunctional one. This may be observable not only at the horizontal level (namely across cells at the same level), but also and more often in the vertical (across layers of cells). Applying this idea to states and their institutional settings, Frey and Luechinger (2004) analogously argue that lower-tier governments and administrations can take over responsibilities of dysfunctional either higher-tier or other lower-tier decision-making and executing institutions. In contrast, in unitary countries non-functioning and destroyed (political and administrative) centers are likely to lead to country-wide collapse. Thus, decentralization may stabilize the polity and, at the same time, reduce the damage of terror on the governance structure, as decentralized countries recover more quickly. Consequently, Frey and Luechinger (2004) expect 'spatial decentralization' - related to some kind of vertical division of 'decision-making' power but also 'implementation' power between various tiers of government - to deter terror. These considerations lead to our first hypothesis.

\footnotetext{
${ }^{2}$ Gassebner et al. (2007a, b) provide empirical evidence. According to their results, terrorists are at least to some extent successful in destabilizing the political system, as terror attacks increase the probability of cabinet dissolutions. Two additional intermediate goals of terrorists, as discussed in Frey and Luechinger (2004), are to attract publicity and media attention, and to damage the economy to incur material costs on the population. As these aims are not directly related to decentralization, we do not discuss them here. See Schnellenbach (2006) for a recent discussion of terrorists' motives.
} 
Hypothesis 1: Decentralization reduces the number of terrorist incidents.

The impact of decentralization on the occurrence of transnational terror is, however, not as obvious as it might look at first sight. Applying more traditional arguments that relate to the quality of public safety, decentralization might create coordination problems which may delay or prevent reforms, thus making terror prevention less effective. ${ }^{3}$ Moreover, institutional constraints imposed by divided powers in decentralized countries might significantly weaken the federal and local governments' ability to fight both domestic and transnational terror. More specifically, horizontal information externalities might imply the underprovision of policy innovation, preventing sensible institutional reforms that may aggravate these coordination problems and inefficiencies (Rose-Ackerman 1980, Strumpf 2002). ${ }^{4}$ Moreover, competition between jurisdictions might cause a "race to the bottom," driving local tax rates below the level necessary to sufficiently finance public goods such as public safety, leading to their underprovision. ${ }^{5}$ In general, small jurisdictions might prevent internalization of positive externalities created by locally produced public goods and, thus, lead to understaffing of security forces. Consequently, decentralization might allow foreign terrorists to organize and manoeuvre more easily, thereby reducing the costs of transnational terrorist activity. ${ }^{6}$

In addition, as Li (2005) argues, policy inaction and political deadlock arising from constraints on central government power (such as decentralized decision-making structures) might heighten public frustration, thereby making it easier for transnational terrorist groups to recruit locally. Indeed, local residents might prefer the participation in already existing and well-established transnational terror networks over building up an own local terror group from scratch, due to lower costs and lower uncertainty with respect to the 'success'? Finally, according to $\mathrm{Li}$ (2005), the abundance of potential targets for terrorist acts makes it easier for

\footnotetext{
${ }^{3}$ Prud'homme (1995) and Sewell (1996) provide support for this view.

${ }^{4}$ However, Kotsogiannis and Schwager (2005) show that policy innovation might even occur more frequently in decentralized systems once politicians' electoral motives are taken into account.

${ }^{5}$ Empirical evidence is, however, not in favour of this hypothesis. For example, Dreher (2006) does not find a significant impact of an index of globalization on tax competition in the OECD. See also Dreher, Gaston and Martens (2008).

${ }^{6}$ As one example, one might think of the coordination failure between the various state and federal institutions in the U.S. that prevented an early detection of the World Trade Tower attacks.

${ }^{7}$ For example, it might be easier to attract media attention and thus to destabilize the polity through fear, as reputation has already been built up.
} 
terrorists to threaten a country's population. To the extent that the number and availability of 'symbolic' targets increases with a country's political and fiscal decentralization, on the one hand, a country may become a more attractive target for foreign terrorists, and, on the other, participation of local residents in transnational groups may become a more attractive means of expressing 'voice' ${ }^{8}$ In consequence, decentralization may make countries more vulnerable to foreign terrorists' activities and their local support, as the marginal costs of committing attacks are reduced, and we should expect transnational terror to be more frequent in such decentralized countries.

We thus hypothesize:

Hypothesis 2: Decentralization increases the number of terrorist incidents.

\section{Measuring Decentralization and Terror}

Frey and Luechinger (2004) discuss the effects of two forms of decentralization decentralization of 'policy implementation' and of 'political decision-making' (ibidem, p.512). Thus, their notion of decentralization captures the two dimensions of 'federalism' as defined by, e.g., Keman (2000) or Brennan and Buchanan (1980). According to Keman (2000), federalist structures comprise decentralization with respect to "the right to act," on the one hand, and "the right to decide," on the other. ${ }^{9}$ In general, political scientists seem to agree that federal structures include "a set of jurisdictional arrangements for allocating policy responsibilities between different levels of government; this refers to both policy-making and policy implementation." (Italics by us) (Obinger et al., 2005, p.9).

However, Frey and Luechinger (2004) argue that both decision-making and policy implementation constitute two separate dimensions of a well-functioning decentralized system. Thus, our analysis accounts for these two types of decentralization. Specifically, we distinguish between decentralization in government spending and local political autonomy. The first most closely reflects the implementation of government policies through executing administrations and public goods creation ("the right to act," Keman 2000), while "local political autonomy' refers to the presence of political decision- and law-making power at the local level ("the right to decide" Keman 2000). In political science, this latter concept is also referred to as decision decentralization or local autonomy (e.g., Treisman 2000).

\footnotetext{
${ }^{8}$ However, the value of each particular target might decrease with the number of available targets.

${ }^{9}$ Similarly, Brennan and Buchanan (1980) define 'federalism' to comprise two dimensions: (i) joint assignment of functions and (ii) taxing power of lower levels of government.
} 
Fiscal decentralization is measured employing data from the IMF's Government Finance Statistics (GFS), as presented in a dataset compiled by the World Bank. ${ }^{10}$ The numerator of these measures is total expenditure of sub-federal government tiers, while the denominator is total spending by all levels of government. ${ }^{11}$ Data are employed for the period 1976-2000 for a maximum of 109 countries. ${ }^{12}$ Among the countries in our sample, spending decentralization is in the range of 1.65-55.62 percent. On average, 21.48 percent of government spending takes place at the sub-federal level (median: 20.27 percent).

Furthermore, we employ a dichotomous indicator of political autonomy of second tier governments that takes on the value of 'one' if "subnational legislatures have autonomy in certain specified areas - i.e., constitutional authority to legislate - not explicitly subject to central laws," collected by and obtained from Treisman (2002). In other words, political autonomy is assumed to exist when the federal constitution stipulates that laws of the second tier cannot be overruled by federal legislation or that no right to framework legislation by the federal government exists (Riker 1964). Prominent examples of such autonomous sub-federal entities are the U.S. states, which also differ in their legal systems, and the Swiss 'cantons', in contrast to the German 'Laender', where only policing and schooling are truly independent state responsibilities. Among our sample of countries, about 16 percent are coded as federal with politically autonomous sub-federal tiers.

However, note that despite the fact that our measure of fiscal decentralization seems to be those used most widely in empirical cross-national studies on the effects of centralization (e.g. Lijphart 1977, Fisman and Gatti 2002), ${ }^{13}$ it is not free of problems. Kessing, Konrad and Kotsogiannis (2006) provide a summary: First, the sources of the revenues, intergovernmental transfers, and other grants are not taken into account. Second, they do not account for the

\footnotetext{
${ }^{10}$ See http://www1.worldbank.org/publicsector/decentralization/fiscalindicators.htm (July 6, 2007).

11 An alternative measure of fiscal decentralization employed in the literature on federalism relates to decentralization of revenue. Revenue decentralization is highly correlated with expenditure decentralization $(\rho=$ 0.94). Our main results reported later are robust to the choice of measure. Moreover, inclusion of both measures of fiscal decentralization shows the dominance of spending decentralization over revenue decentralization. Finally, fiscal decentralization is often measured as tax revenue dependence on the central government ( $\rho$ (spending decentralization, own tax dependence) $=0.19$ ). Replacing spending decentralization with this tax autonomy measure yields insignificant coefficients in all models of Tables 1 and 2.

${ }^{12}$ Selection of countries and years is driven by data availability.

${ }^{13}$ While this is true for cross-country studies, other political institutions such as direct democracy may be more important for the provisions of public goods on the state level within a country. For example, Fischer (2005) investigates whether direct democracy restricts the Leviathan like behavior of bureaucracies using an index of direct democracy.
} 
extent to which the jurisdictions' tax bases overlap. ${ }^{14}$ Third and most importantly, these data reflect only the distribution of spending responsibilities but do not contain information about the distribution of political power among the central and sub-national governments. It is for this reason we measure political autonomy separately.

Turning to our measure of terrorist activity, we employ data provided in the MIPT Terrorism Knowledge Base. ${ }^{15}$ The Terrorism Knowledge Base integrates data from the RAND Terrorism Chronology and RAND-MIPT Terrorism Incident databases, the Terrorism Indictment database, and DFI International's research on terrorist organizations. ${ }^{16}$

The Terrorism Knowledge Base defines terror as "violence, or the threat of violence, calculated to create an atmosphere of fear and alarm. These acts are designed to coerce others into actions they would not otherwise undertake, or refrain from actions they desired to take. [...] This violence or threat of violence is generally directed against civilian targets. The motives of all terrorists are political, and terrorist actions are generally carried out in a way that will achieve maximum publicity. Unlike other criminal acts, terrorists often claim credit for their acts. Finally, terrorist acts are intended to produce effects beyond the immediate physical damage of the cause, having long-term psychological repercussions on a particular target audience. The fear created by terrorists may be intended to cause people to exaggerate the strengths of the terrorist and the importance of the cause, to provoke governmental overreaction, to discourage dissent, or simply to intimidate and thereby enforce compliance with their demands." ${ }^{, 17}$ As terrorist acts are defined by their nature (violent and criminal acts), they are included in the database irrespective of the identity of the committing group or their long-term goals. In principle, terrorist acts might well be carried out by the violent branch of the political opposition to the ruling government (e.g. the RAF in Germany).

In this paper, we focus on incidences of transnational terrorism. ${ }^{18}$ According to MIPT, transnational terror events are defined according to (1) the provenience of the terrorist or their group or (2) the nature of the terrorists' targets. Thus transnational terrorisms involves either terrorists acting in a foreign country, domestic targets that are associated with a foreign

\footnotetext{
${ }^{14}$ See Treisman (2002) and Ebel and Yilmaz (2002) for a more detailed discussion.

${ }^{15}$ Available at: http://www.tkb.org/.

${ }^{16}$ There are various sources for terrorism data. We choose MIPT because it combines various sources and thus provides extensive country and yearly coverage. For a detailed discussion on the measurement of terrorism see Frey and Luechinger (2003b).

${ }^{17}$ See the glossary that accompanies the MIPT database. See also Enders and Sandler $(1999,2002)$.

${ }^{18}$ While our hypotheses directly refer to transnational terrorism, there is an additional reason for excluding domestic terror: reliable panel data on domestic terrorism is only available for a short (and recent) period of time.
} 
country (such as embassies), or targets of an international character (such as airplanes or UNrelated entities). According to this definition, attacks of local residents against their own governments are only counted as transnational terror events if they occur in the name of an internationally working network of terrorists, such as, e.g., Al Qaeda. In contrast, attacks of foreigners would always be counted as 'transnational' incidences. ${ }^{19}$

We extract the number of transnational terror events for each country and year. ${ }^{20}$ Given that the database covers the whole world, we assign zeros to all countries and years without data. According to our sample of 109 countries from 1976-2000, the number of terrorist events per country during the total sample period varies from 0 to 50 with an average of about 1.70 (or 4.57 for those country-year observations with positive values). Altogether, there were 710 country-years with actual incidences of transnational terror in our panel (and 1911 country-year observations altogether). Appendix C presents the average number of transnational terrorist events in the world by year.

\section{Figure 1: Development of Transnational Terror over time}

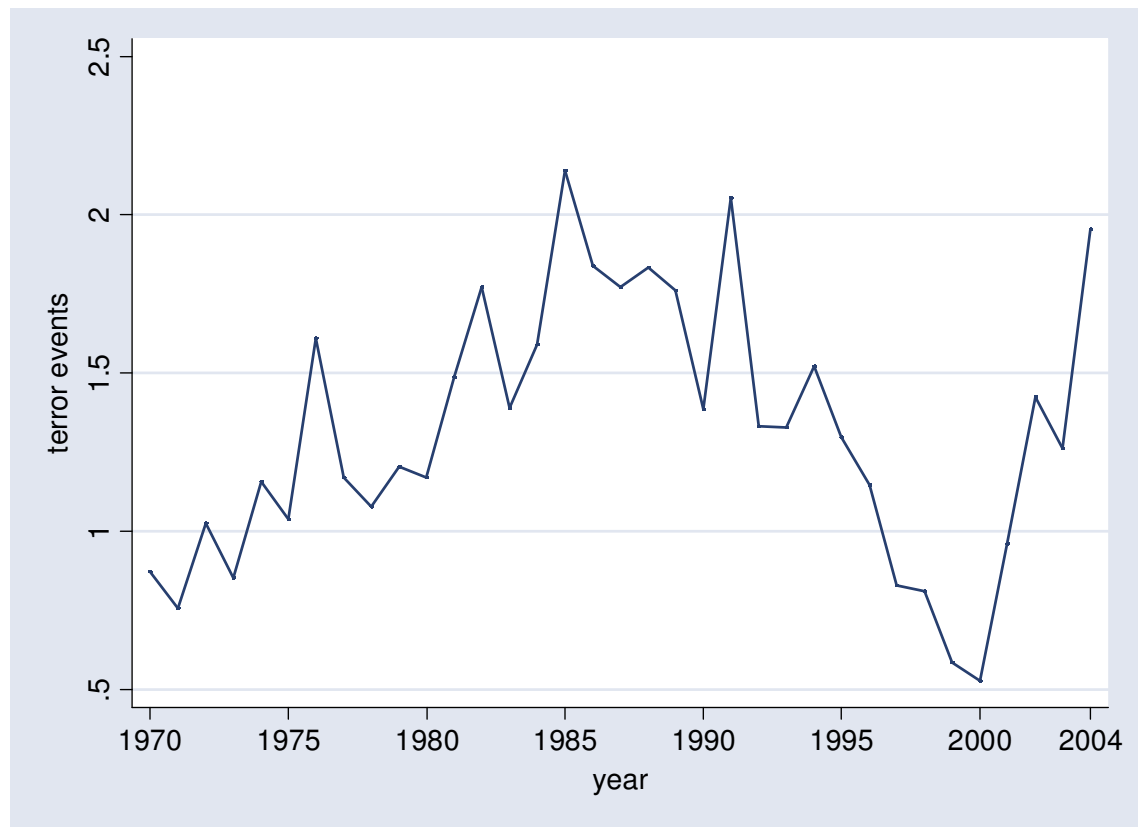

\footnotetext{
${ }^{19}$ The definition of MIPT for transnational events is close to that of Sandlers and Enders (2004), who base it on either the terrorist group's international ramifications or its foreign interest as target.

${ }^{20}$ Territories are assigned to the country formally governing the territory. Kashmir and the Persian Gulf are excluded as it is not obvious to which country they should be assigned to.
} 
Figure 1 shows how the average number of terror events per country has evolved over time. ${ }^{21}$ As shown in Appendix C, the average number of transnational terror events fluctuates around the mean from 1976 to 1996, slightly declines from 1996 on, and rises again after 2000.

\section{Method}

We estimate pooled time-series cross-section regressions for panel, non-negative count data. The data extend to a maximum of 109 countries and cover the years 1976-2000. Since some of the data are not available for all countries or years, the panel data are unbalanced and the number of observations depends on the choice of explanatory variables. As our data on terror events are strongly skewed to the right (with an accumulation of observations at zero) and display significant overdispersion (with the variance being greater than the mean), we estimate our regressions employing the Negative Binomial estimator. ${ }^{22}$

Our basic equation takes the following form:

$$
\text { terror }_{i t}=\alpha+\beta_{1} \text { decent }_{j i t-1}+\beta_{2}^{\prime} X_{i, t-1}+\lambda_{t}+\varepsilon_{i t} \text {, }
$$

where terror $_{i t}$ represents the number of recorded transnational terror events in country $i$ in period $t$, and decent $t_{j i t-1}$ is our $j^{\text {th }}$ (lagged) measure of decentralization. $X_{i, t-1}$ is the vector of (lagged) control variables, $\lambda_{t}$ are fixed time effects, while $\varepsilon_{i t}$ represents the disturbance. The low correlation between political and fiscal decentralization allows their joint inclusion. ${ }^{23}$ As local autonomy shows no time series variation, the model is estimated with random effects. Note that the Hausman test favours this model over pooled Negative Binomial regressions. When testing for robustness employing fixed effects (and omitting local autonomy) the main results are unchanged.

Note that our analysis focuses on the targets of terrorism rather than its sources. In choosing our control variables, we thus follow Dreher and Gassebner (2007) who also analyze the targets of terror. We employ GDP per capita (measured in constant 2000 US\$). On the one hand, richer countries are more attractive targets for terrorists, as terror creates more attention.

\footnotetext{
${ }^{21}$ For time-series studies on the occurrence and distribution of terrorism see Enders and Sandler (2005, 2006).

${ }^{22}$ Applying OLS would bias the estimates due to the truncation at zero and the overproportional occurrence of zero incidences in the distribution. However, the OLS estimates are qualitatively identical to those count model results reported below.

${ }^{23}$ Correlation between political and fiscal decentralization is 0.4 .
} 
On the other hand, richer countries can afford stronger police and intelligence agencies, potentially being able to prevent terror. The impact of per capita GDP is thus not obvious a priori.

A second variable suggested to be important for terror is civil liberty, that comprises mainly political participation possibilities, but also aspects of economic and social freedom as well as a well-functioning impartial juridical system (see Freedom House 2005). The relation between political freedom and terrorism is also ambiguous a priori. Repressive states could foster terrorism (as minorities might conceive participation in transnational terror networks as the only "effective communication device" against state repression) or be detrimental to it (as repressive states might be better able to suppress terrorism in general). According to $\mathrm{Li}$ (2005), democracy reduces the number of terrorist events, while Li and Schaub (2004) - not accounting for government constraints - show the opposite. As Frey and Luechinger (2003a, 2004) argue, stronger democracy might serve as political stabilizer, decreasing the marginal benefit of terrorist acts, with democratic discussion culture serving as an alternative option to participation in transnational terrorist activities as means of expressing discontent, thus raising the terrorists' opportunity costs. ${ }^{24}$ In line with Piazza (2006) and Dreher and Gassebner (2007), we include both the level of and changes in political freedom.

Third, we include population size, as transnational attacks in larger countries might attract greater international media attention. In addition, larger populations tend to be more heterogeneous in their preferences which may give rise to societal conflicts. Furthermore, the costs of state surveillance and policing might rise with population size (Piazza 2006).

Fourth, we include government fractionalization. According to Piazza (2006), the number of parties in power to some extent proxies for "social cleavage," potentially giving rise to terror. Conflicting political interests might in particular extend to the foreign-based population. On the other hand, coalition governments may represent a larger portion of the population and a larger number of social groups compared to a single party government (Lijphart 1977), which may decrease the likelihood that people choose terrorism to express their 'political' preferences.

Finally, we include data on voting coincidence with the U.S. in the UN General Assembly as provided by Voeten (2004). As shown in Dreher and Gassebner (2007),

\footnotetext{
${ }^{24}$ Sandler (1995) provides an excellent discussion of the early literature on the relationship between democracy and terror. A present-time example of the relation between missing political freedom and 'imported' transnational terrorism (partly executed by local residents) is Iraq.
} 
countries voting more frequently in line with the U.S. in the Assembly are more likely to become victims of terror. We follow Thacker (1999), coding votes in agreement with the U.S. as 1 , votes in disagreement as 0 , and abstentions or absences as 0.5 . The resulting numbers are then divided by the total number of votes in each year. This results in a variable ranging from zero to one, with zero indicating total disagreement with the U.S., and one showing full agreement.

Data for per capita GDP and population are taken from the World Bank (2006). Government fractionalization is from Beck et al. (2001) and measures the probability that two randomly drawn members from among the government are of different parties. Level and change in political freedom are based on the average of political rights and civil liberties from Freedom House (2005). Higher values represent more liberty, on a scale from -7 (low) to -1 (high).

\section{Results}

Table 1 shows the results. We first include fiscal decentralization and political autonomy separately (columns 1 and 2), while column 3 includes them jointly. All models include dummies for each year, which are always jointly significant at the one percent level. Overall, our results mirror those reported in Piazza (2006) and Dreher and Gassebner (2007). In tendency, the number of terror events increases with greater social and ethnic cleavages as measured by government fractionalization and population size. ${ }^{25}$ Possibly, attacks in more populous countries might trigger a larger international media response. In two of the three specifications, terror also rises with the level of civil liberties and greater voting coincidence with the U.S. in the UN General Assembly, at least at the ten percent level of significance. Possibly, the latter also captures the proximity of a country's foreign policy to that of the U.S., making the country a 'substitute target', with possibly lower 'entry' costs. GDP per capita is not consistently significant at conventional levels, which is consistent with Krueger and Malečková (2003) and Abadie (2006). Changes in political freedom have no significant impact on terror according to all specifications.

Turning to our variables of primary interest, the results show a significant effect of expenditure decentralization on terror. At the ten percent level of significance at least, our

\footnotetext{
25 The coefficients are significant at the five percent level at least - with the exception of government fractionalization which is marginally insignificant according to column 3.
} 
results show that fiscal decentralization reduces the number of terror events. The result is in line with our a priori hypothesis regarding the division of spending responsibilities across government tiers. Calculating the marginal effect of fiscal decentralization associated with the full model of column 3, the results show that the number of terror events a country is exposed to declines by 0.03 with an increase in decentralization by one percentage point. Thus, for example, evaluated at the mean, the model predicts that raising the share of sub-federal spending from $20 \%$ to $50 \%$ will reduce the number of incidences by almost half from 1.49 to 0.76. Clearly, this impact is quantitatively relevant and bears important welfare implications. ${ }^{26}$

The results of columns 2 and 3 also show that local political autonomy does not affect the number of terror events, neither separately nor when jointly included with fiscal decentralization. This finding contradicts the hypothesis that more political autonomy deters terrorism through its structure-stabilizing effect on the political system. Potentially, the insignificance of political autonomy might be caused by two opposing effects: on the one hand, local decision-making power might well decrease terrorists' marginal benefits through political stabilization (Frey and Luechinger 2004), but on the other hand, a politically decentralized government may also provide more potential symbolic-bearing targets for terrorist attacks, as Li (2005) argues. Unfortunately, both effects cannot be disentangled.

Column 4 tests for the robustness of our results to changes in the definition of the dependent variable. We replace the dependent count variable by a dichotomous indicator reflecting the occurrence of any transnational terror event that takes the value ' 1 ' if at least one transnational terrorist act was recorded and ' 0 ' otherwise. As can be seen, the previous results are confirmed. While fiscal decentralization reduces the likelihood that terror events occur, autonomy has no significant effect. More specifically, evaluated at the mean, raising the degree of fiscal decentralization from $20 \%$ of total spending to $50 \%$ decreases the probability that a transnational terror event occurs from $39 \%$ down to $18 \%$.

Finally, we instrument spending decentralization to take into account that countries experiencing terrorist acts (or some pre-modern form of it as, e.g., peasant riots, 'Robin Hoods', etc.) might deliberately choose a centralized form of political and administrative governance. ${ }^{27}$ As instruments we use a country's land area, the population share of persons

\footnotetext{
${ }^{26}$ See Frey, Luechinger and Stutzer (2004) for an attempt to measure the welfare costs of terrorism.

${ }^{27}$ The effect of spending decentralization might also be driven by correlated variables we do not control for in the regressions. For example, the effect might be driven by higher spending on military in more centralized countries, either attracting terrorist activities or being a reaction to it. However, the simple correlation between the $\log$ of military spending as share of GDP with fiscal decentralization is less than -0.06 , and the partial
} 
older than 60 (obtained from the World Bank's World Development Indicators) and a measure of ethnic fractionalization. We conjecture that all three variables clearly account for historical roots of and socio-demographic causes for developing decentralized governance structures: Clearly, in pre-modern times with inefficient means of communication, larger countries were more likely to be in need for developing a multi-tier administrative system to achieve effective governance, while ethnic fractionalization accounts for the heterogeneity of preferences in the population. On the one hand, modern economic theory claims that the latter can be more efficiently targeted in decentralized systems, while historically, a heterogeneous population was traditionally perceived by the ruler as threat to unity and citizen loyalty, leading to centralized government structures and policies. ${ }^{28}$ Finally, a (relatively) overaging population today may be the result of economic success in the past, e.g. driven by an early industrialization about 100 years ago. In principle, we may argue that more wealth in the past and a broader tax base made the development of several layers of governance financially affordable, leading to path dependence effects explaining today's degree of decentralization.

We provide three specifications. First, we estimate the instrumental variable model using 2SLS. Second, we employ Tobit; and third, we estimate it using Probit (with clustering at the country level), where the dependent variable is again the binary indicator for the occurrence of any transnational terror event. The Tobit model takes into account that the dependent variable has only positive values, but neglects its count characteristics, while 2SLS assumes continuity into the positive and negative space. The endogeneity of decentralization is tested based on all three model specifications.

Turning to the validity of our instruments, the instruments meet the exclusion restriction insofar as they are neither individually nor jointly significant in the first stage regression (conditional on all exogenous variables). In an auxiliary OLS first stage regression all three instruments explain the instrumented variable jointly well, with an F-statistic meeting the rule-of-thumb threshold of ten $(F(3,59)=10.72$; Staiger and Stock 1987), a Shea partial $\mathrm{R} 2$ of 0.25 and an overall first stage $\mathrm{R}^{2}$ of 0.47 . Individually, each of the instruments is significant at least at the 5 percent level. As predicted, the size of the land area and an aging

correlation controlling for democratic rights and GDP is even lower in absolute values. Missing data on military spending for many countries and years prevents us from including this variable in the regression analysis.

${ }^{28}$ As well-known example consider France's centralization process from the $15^{\text {th }}$ century onwards that led to the continuous loss of autonomy of formerly quite independent dukedoms and regions such as languedoc (Montpellier), the Bretagne, and the Alpine dukedom of Savoyen. It was due to this policy that the city-republic of Geneva joined the federal country Switzerland in 1815. In general, religion cleansing policies that occurred over the last centuries in many countries can also be seen in this light. 
population are positively correlated with fiscal decentralization, while the coefficient of ethnic fractionalization indicates that it leads to more centralized governance structures.

Assuming cardinality in the outcome variable, the 2SLS estimates with clustering at the country level (shown in column 5) reveal that the instruments are valid. They successfully pass the Hansen $\mathbf{J}$ test $(\chi 2(1)=0.08$, p-value $=0.96)$, the Anderson-Rubin Wald test of weak instruments $(F(2,59)=2.03$, p-value $=0.12)$, both indicating that the overidentifying restrictions are valid, and the Kleibergen-Paap test, ${ }^{29}$ which rejects the null hypothesis of underidentification (for the LM version: $(\chi 2(2)=14.71$, p-value $=0.00$ ). According to the Stock-Yogo weak ID test critical values, the bias in the IV estimator due to weak instruments is between $5 \%$ and $10 \%$.

Testing for the exogeneity of spending decentralization using either IV Tobit, 2SLS or IV Probit does not reject the null hypothesis suggesting that the endogenous regressor can be treated as exogenous. ${ }^{30}$ Not unsurprisingly, instrumented spending decentralization still reduces the number of terror events, at the five percent level of significance. Moreover, given the non-rejection of exogeneity we should expect the estimates for decentralization to be of comparable magnitude across instrumented and non-instrumented specifications. In fact, comparing the marginal effects (evaluated at the mean) for instrumental variable Probit (IV Probit), pooled Probit clustered at the country level, and random effects Probit yields almost identical estimates (-0.0087 vs. -0.0083 and -0.0079 , respectively).

As next step, we separate those transnational terror events that can be considered to be marginal from those which are severe. For the latter, we count all terrorist events in which at least one person was physically harmed - namely all events in which the number of persons killed or the number of persons injured was greater than zero. Of course, it is debatable which threshold constitutes a severe event. Following Dreher, Gassebner and Siemers (2007), we choose the lowest threshold possible. While this is the most objective choice from our point of view, we are clearly aware that events in which no one is physically harmed may still have a major psychological or economic impact on the population as, e.g., the London bombings of July 21, 2005.

In Table 2, we report results employing the negative binomial estimator (columns 1 and 2), panel Logit (columns 3 and 4), and IV Probit (columns 5 and 6). According to all regressions, the overall results observed previously seem to be driven by severe events.

\footnotetext{
${ }^{29}$ Rejection occurs both as LM test and as Wald test. For the latter, we observe $(\chi 2(2)=31.45$, p-value $=0.00)$.

${ }^{30}$ In 2 SLS, the corresponding test statistics are $\chi 2(1)=1.37$ with prob $>\chi 2=0.24$, in the IV Tobit, the Wald test statistics are $\chi 2(1)=1.02$ with prob $>$ chi $2=0.31$, and in the IV Probit, the test statistics are chi $2(1)=0.57$ with prob $>$ chi $2=0.45$.
} 
Significant at the ten percent level at least, fiscal decentralization reduces the number and, respectively, the probability of severe terror events but does not affect less severe events at conventional levels of significance. According to the marginal effects in the count model, an increase in fiscal decentralization reduces the number of severe terror events by 0.15 , an effect quantitatively about 5 times larger than the one observed for both severe and marginal events. For illustration, a rise in the degree of spending decentralization from $20 \%$ to $50 \%$, which is realistic given the variation in our regression sample from $1.5 \%$ to $55.6 \%$, would decrease the number of severe terror events by roughly 2.7, from 3.9 down to 1.2. Compared to the effect for all transnational events, the decrease in absolute terms is more than quadruple in size (-0.63 versus -2.7$)$.

Table 3 tests for the robustness of our results to the inclusion of additional variables that have been proposed as determinants of terror in the previous literature or are intuitively appealing as such. As in Piazza (2006) and Dreher and Gassebner (2007), we test for the sensitivity of the estimates to the inclusion of population growth and GDP growth. According to Piazza (2006), the first puts pressure on a countries' economic and political system, increasing terrorism, while, following the literature on conflicts, negative exogenous shocks in the latter, may increase the likelihood of civil conflict. However, GDP growth may equally well be correlated with reductions in poverty, potentially mitigating social cleavages.

In addition to government fractionalization that is included in the main regression, we also test four alternative measures of 'social cleavage' and heterogeneous preferences in the population: ethnic fractionalization, language fractionalization, religion fractionalization, and fractionalization of the parliamentary opposition. Furthermore, recently founded states might have still weak and ineffective institutions, thus not (yet) being able to channel preferences of some social groups into the political decision-making process, serving as political stabilizers. Finally, we include a dichotomous variable that takes the value 'one' if the country is in a state of internal or external war. Again, analogously to the previous argument, we can expect some government institutions to not work well and some basic human rights to be severely constrained during times of war giving rise to social grievance.

As can be seen from Table 3, most of the additional variables are completely insignificant. The exceptions are the war dummy and the dummy for new states that are significant at the five percent level, with a positive and, respectively, a negative coefficient. Most importantly, however, the negative impact of expenditure decentralization on terror stays significant at the five percent level at least according to all specifications. Moreover, its 
coefficient is of similar size across all estimated models, which shows that decentralization is not strongly correlated with any of the additional determinants included to the model.

We conclude that our results are robust to the choice of method and control variables, as well as controlling for endogeneity. ${ }^{31}$

\section{Summary and Conclusion}

This paper empirically analyzed the impact of decentralization on the occurrence of transnational terror using panel data for a maximum of 109 countries over the years 19762000. Taking account of the potential simultaneity between terror and decentralization we find that expenditure decentralization robustly reduces the number of terror events in a target country, while political decentralization has no impact. In the words of Keman (2000), we find the 'power to act (= spend)' to matter more than the 'power to decide' for the fight against transnational terrorism.

Building closely on Frey and Luechinger (2004) - but distinguishing decentralization of policy implementation from decentralization of political decision-making - we argue that effective local government administrations (potentially taking over responsibilities from other dysfunctioning local or supra-local administrations) are more important in stabilizing a country than the dispersion of actual decision-making authority at the local level. In addition, local spending autonomy may increase competition among jurisdictions, thereby improving the quality of the public good 'security'.

Our results bear important policy implications. Since the seminal work of Becker (1968), economists view undertaking criminal acts as the outcome of rational decisionmaking. Applying this rational choice model of criminal behavior to terrorists' decisions, additional terror will occur when the expected marginal benefit of an additional terrorist act outweighs its marginal costs. Indeed, it has been shown that the propensity to commit terrorist acts can be influenced by changes in external costs and benefits (Enders and Sandler 1995). Traditional strategies for combating terror aim at raising the direct or opportunity costs of committing such acts, while more recent approaches focus on reducing the (expected) benefits of terrorist activity, particularly in light of failing deterrence strategies (Lichbach 1987, Frey 1988, Sandler and Enders 2004, Wilkinson 2002). In this paper, we have shown that greater spending decentralization might be one instrument to influence terrorists' marginal costs and

\footnotetext{
31 We also replicated the analysis for a sample of countries without political autonomy. The results are unchanged.
} 
benefits of their acts, reducing the occurrence of transnational terror. Previous research has argued that decentralized spending competences lead to inefficient overspending and create problems of coordination, thereby preventing effective security and finally making a country more attractive for terrorist activity. As we have shown in this paper, on average, the opposite is true. According to these results some policy makers' calls for greater centralization in the 'fight against terrorism' should be treated with caution.

\section{Acknowledgements:}

We thank Martin Gassebner, Magnus Johannesson, Simon Luechinger, Panu Poutvaara, Todd Sandler and seminar participants at the Stockholm School of Economics and the Norwegian University of Science and Technology (Trondheim) for helpful comments on an earlier draft. The second author thanks the KOF Swiss Economic Institute, ETH Zurich, for its generous hospitality and the Marie Curie fellowship scheme for funding. 
Table 1: Decentralization and Terror, 1976-2000

\begin{tabular}{lccccccc}
\hline & $(1)$ & $(2)$ & $(3)$ & $(4)$ & $(5)$ & $(6)$ & $(7)$ \\
\hline Fiscal decentralization (t-1) & $-0.015^{*}$ & & $-0.022^{* * *}$ & $-0.035^{* *}$ & $-0.162^{* *}$ & $-0.310^{* *}$ & $-0.029^{* *}$ \\
& {$[1.82]$} & & {$[2.65]$} & {$[2.32]$} & {$[2.27]$} & {$[2.38]$} & {$[2.34]$} \\
Political autonomy & & 0.321 & 0.139 & 0.141 & 0.671 & 1.228 & 0.287 \\
& & {$[1.43]$} & {$[0.49]$} & {$[0.27]$} & {$[0.55]$} & {$[0.62]$} & {$[1.20]$} \\
(log) GDP per capita (t-1) & $0.219^{* *}$ & 0.104 & 0.174 & 0.297 & 0.257 & 1.055 & 0.099 \\
& {$[2.13]$} & {$[1.44]$} & {$[1.59]$} & {$[1.54]$} & {$[0.79]$} & {$[1.40]$} & {$[0.98]$} \\
(log) Population (t-1) & $0.462^{* * *}$ & $0.160^{* *}$ & $0.407 * * *$ & $0.837^{* * *}$ & $1.255^{* * *}$ & $3.268^{* * *}$ & $0.417 * * *$ \\
& {$[4.98]$} & {$[2.48]$} & {$[3.85]$} & {$[5.22]$} & {$[2.66]$} & {$[3.08]$} & {$[4.15]$} \\
Political freedom (t-1) & $0.104^{*}$ & 0.034 & $0.151^{* *}$ & 0.170 & 0.405 & $1.020^{*}$ & $0.159^{* *}$ \\
& {$[1.71]$} & {$[0.81]$} & {$[2.25]$} & {$[1.48]$} & {$[1.39]$} & {$[1.93]$} & {$[2.11]$} \\
Political freedom, change & -0.002 & -0.102 & 0.013 & 0.175 & -0.594 & -0.384 & 0.117 \\
& {$[0.01]$} & {$[1.31]$} & {$[0.10]$} & {$[0.73]$} & {$[0.88]$} & {$[0.30]$} & {$[0.82]$} \\
Government fractionalization (t-1) & $0.538^{* *}$ & $0.548^{* * *}$ & 0.418 & 0.765 & 0.377 & 1.593 & 0.302 \\
& {$[2.27]$} & {$[3.20]$} & {$[1.62]$} & {$[1.64]$} & {$[0.25]$} & {$[0.57]$} & {$[0.93]$} \\
Voting with U.S. (t-1) & $1.458^{* *}$ & 0.557 & $1.524^{* *}$ & 1.709 & 13.795 & 20.002 & 1.557 \\
& {$[2.05]$} & {$[1.03]$} & {$[2.04]$} & {$[1.23]$} & {$[1.59]$} & {$[1.57]$} & {$[1.53]$} \\
Constant & $-10.735^{* * *}$ & $-3.223^{* *}$ & $-9.220^{* * *}$ & $-17.609 * * *$ & & $-59.769 * * *$ & $-6.847^{* * *}$ \\
& {$[5.34]$} & {$[2.31]$} & {$[3.99]$} & {$[5.11]$} & & {$[2.83]$} & {$[3.34]$} \\
\hline Observations & 934 & 1911 & 826 & 826 & 685 & 685 & 685 \\
Number of countries & 76 & 109 & 63 & 63 & 60 & 60 & 60 \\
Method & NBR & NBR & NBR & Logit & $2 S L S$ & IV Tobit & IV Probit \\
Wald test (Prob>chi2) & 0.00 & 0.00 & 0.00 & 0.00 & 0.00 & 0.00 & 0.00 \\
\hline
\end{tabular}

Notes:

The dependent variable is the number of transnational terror events in a particular year and country (columns 1-3, 5-7) or a dummy with value ' 1 ' if a terrorist event occurs (column 4).

Time dummies are included in all regressions.

Absolute value of $\mathrm{z}$ statistics in brackets.

$*$ significant at $10 \% ; * *$ significant at $5 \% ; * * *$ significant at $1 \%$ 
Table 2: Decentralization and Terror according to severity, 1976-2000

\begin{tabular}{lcccccc}
\hline & $(1)$ & $(2)$ & $(3)$ & $(4)$ & $(5)$ & $(6)$ \\
& severe & less severe & severe & less severe & severe & less severe \\
\hline Fiscal decentralization (t-1) & $-0.040^{* * *}$ & 0.007 & $-0.040^{* *}$ & -0.003 & $-0.033^{*}$ & -0.001 \\
& {$[4.12]$} & {$[0.71]$} & {$[2.18]$} & {$[0.27]$} & {$[1.94]$} & {$[0.12]$} \\
Political autonomy & -0.378 & 0.214 & -0.786 & 0.527 & 0.093 & 0.21 \\
& {$[1.29]$} & {$[0.71]$} & {$[1.19]$} & {$[1.50]$} & {$[0.45]$} & {$[1.26]$} \\
(log) GDP per capita (t-1) & 0.132 & 0.187 & 0.288 & 0.254 & 0.032 & 0.141 \\
& {$[1.01]$} & {$[1.32]$} & {$[1.19]$} & {$[1.54]$} & {$[0.26]$} & {$[1.59]$} \\
(log) Population (t-1) & $0.625^{* * *}$ & 0.099 & $1.043 * * *$ & $0.214^{*}$ & $0.407 * * *$ & 0.100 \\
& {$[5.24]$} & {$[0.91]$} & {$[4.75]$} & {$[1.79]$} & {$[3.84]$} & {$[1.23]$} \\
Political freedom (t-1) & $0.216^{* * *}$ & -0.051 & $0.359^{* * *}$ & -0.050 & $0.163 *$ & 0.016 \\
& {$[2.61]$} & {$[0.49]$} & {$[2.72]$} & {$[0.43]$} & {$[1.87]$} & {$[0.23]$} \\
Political freedom, change & 0.065 & 0.037 & 0.240 & 0.053 & 0.094 & 0.061 \\
& {$[0.34]$} & {$[0.18]$} & {$[0.90]$} & {$[0.21]$} & {$[0.81]$} & {$[0.45]$} \\
Government fractionalization (t-1) & $0.601^{*}$ & -0.162 & $1.134 * *$ & -0.110 & 0.365 & -0.058 \\
& {$[1.77]$} & {$[0.41]$} & {$[2.15]$} & {$[0.23]$} & {$[1.22]$} & {$[0.24]$} \\
Voting with U.S. (t-1) & $2.399^{* *}$ & -0.714 & 0.060 & 0.038 & 1.99 & -0.693 \\
& {$[2.50]$} & {$[0.62]$} & {$[0.04]$} & {$[0.03]$} & {$[1.59]$} & {$[0.71]$} \\
Constant & $-12.962^{* * *}$ & $-5.720^{* *}$ & $-20.299^{* * *}$ & $-8.906 * * *$ & $-6.820^{* * *}$ & $-3.248^{* *}$ \\
& {$[4.84]$} & {$[2.26]$} & {$[4.38]$} & {$[3.14]$} & {$[3.07]$} & {$[1.97]$} \\
\hline Observations & 826 & 826 & 826 & 826 & 685 & 685 \\
Number of countries & 63 & 63 & 63 & 63 & 60 & 60 \\
Method & NBR & NBR & Logit & Logit & IV Probit & IV Probit \\
Wald test (Prob>chi2) & 0.00 & 0.00 & 0.00 & 0.00 & 0.00 & 0.00 \\
\hline
\end{tabular}

Notes:

The dependent variable is the number of transnational terror events in a particular year and country (columns 1 , $2,5,6$ ) or a dummy with value ' 1 ' if a terrorist event occurs (columns 3, 4). A terror event is defined as severe when at least one person has been injured or killed.

All regressions include a dummy for each year.

Absolute value of $\mathrm{z}$ statistics in brackets.

$*$ significant at $10 \%$;* significant at $5 \%$; *** significant at $1 \%$ 
Table 3: Decentralization and Terror, NBR, 1976-2000

\begin{tabular}{|c|c|c|c|c|c|c|c|c|}
\hline & $(1)$ & $(2)$ & (3) & (4) & $(5)$ & (6) & (7) & $(8)$ \\
\hline Fiscal decentralization (t-1) & $\begin{array}{c}-0.022 * * * \\
{[2.64]}\end{array}$ & $\begin{array}{c}-0.022 * * * \\
{[2.62]}\end{array}$ & $\begin{array}{c}-0.023^{* * *} \\
{[2.77]}\end{array}$ & $\begin{array}{c}-0.019 * * \\
{[2.25]}\end{array}$ & $\begin{array}{c}-0.021 * * \\
{[2.48]}\end{array}$ & $\begin{array}{c}-0.025^{* * *} \\
{[2.95]}\end{array}$ & $\begin{array}{c}-0.023^{* * *} \\
{[2.65]}\end{array}$ & $\begin{array}{c}-0.025 * * * \\
{[2.75]}\end{array}$ \\
\hline Political autonomy & $\begin{array}{c}0.139 \\
{[0.49]}\end{array}$ & $\begin{array}{l}0.139 \\
{[0.49]}\end{array}$ & $\begin{array}{l}0.172 \\
{[0.58]}\end{array}$ & $\begin{array}{l}0.266 \\
{[0.96]}\end{array}$ & $\begin{array}{l}0.095 \\
{[0.32]}\end{array}$ & $\begin{array}{l}0.226 \\
{[0.79]}\end{array}$ & $\begin{array}{c}0.131 \\
{[0.46]}\end{array}$ & $\begin{array}{l}0.259 \\
{[0.83]}\end{array}$ \\
\hline (log) GDP per capita (t-1) & $\begin{array}{c}0.185^{*} \\
{[1.68]}\end{array}$ & $\begin{array}{c}0.174 \\
{[1.58]}\end{array}$ & $\begin{array}{c}0.056 \\
{[0.47]}\end{array}$ & $\begin{array}{l}0.165 \\
{[1.57]}\end{array}$ & $\begin{array}{l}0.196 \\
{[1.63]}\end{array}$ & $\begin{array}{l}0.099 \\
{[0.83]}\end{array}$ & $\begin{array}{c}0.177 \\
{[1.59]}\end{array}$ & $\begin{array}{c}0.064 \\
{[0.53]}\end{array}$ \\
\hline (log) Population (t-1) & $\begin{array}{c}0.411^{* * *} \\
{[3.90]}\end{array}$ & $\begin{array}{c}0.407 * * * \\
{[3.85]}\end{array}$ & $\begin{array}{c}0.331 * * * \\
{[3.02]}\end{array}$ & $\begin{array}{c}0.356^{* * * *} \\
{[3.41]}\end{array}$ & $\begin{array}{c}0.413^{* * *} \\
{[3.87]}\end{array}$ & $\begin{array}{c}0.441 * * * \\
{[4.15]}\end{array}$ & $\begin{array}{c}0.409 * * * \\
{[3.85]}\end{array}$ & $\begin{array}{c}0.363^{* * *} \\
{[2.94]}\end{array}$ \\
\hline Political freedom (t-1) & $\begin{array}{c}0.150 * * \\
{[2.23]}\end{array}$ & $\begin{array}{c}0.151 * * \\
{[2.24]}\end{array}$ & $\begin{array}{c}0.159 * * \\
{[2.35]}\end{array}$ & $\begin{array}{c}0.191 * * * \\
{[2.80]}\end{array}$ & $\begin{array}{c}0.159 * * \\
{[2.29]}\end{array}$ & $\begin{array}{l}0.130 * \\
{[1.89]}\end{array}$ & $\begin{array}{c}0.153 * * \\
{[2.25]}\end{array}$ & $\begin{array}{l}0.155^{*} \\
{[1.89]}\end{array}$ \\
\hline Political freedom, change & $\begin{array}{l}0.019 \\
{[0.14]}\end{array}$ & $\begin{array}{l}0.013 \\
{[0.10]}\end{array}$ & $\begin{array}{l}-0.025 \\
{[0.19]}\end{array}$ & $\begin{array}{l}0.010 \\
{[0.07]}\end{array}$ & $\begin{array}{l}0.019 \\
{[0.14]}\end{array}$ & $\begin{array}{l}0.012 \\
{[0.09]}\end{array}$ & $\begin{array}{l}0.014 \\
{[0.10]}\end{array}$ & $\begin{array}{l}-0.034 \\
{[0.24]}\end{array}$ \\
\hline Government fractionalization (t-1) & $\begin{array}{c}0.413 \\
{[1.60]}\end{array}$ & $\begin{array}{c}0.417 \\
{[1.62]}\end{array}$ & $\begin{array}{c}0.377 \\
{[1.45]}\end{array}$ & $\begin{array}{c}0.373 \\
{[1.48]}\end{array}$ & $\begin{array}{l}0.406 \\
{[1.57]}\end{array}$ & $\begin{array}{c}0.448 * \\
{[1.74]}\end{array}$ & $\begin{array}{l}0.420 \\
{[1.63]}\end{array}$ & $\begin{array}{c}0.530 * \\
{[1.88]}\end{array}$ \\
\hline Voting with U.S. (t-1) & $\begin{array}{c}1.519^{* *} \\
{[2.03]}\end{array}$ & $\begin{array}{c}1.524 * * \\
{[2.04]}\end{array}$ & $\begin{array}{c}1.674 * * \\
{[2.18]}\end{array}$ & $\begin{array}{l}0.996 \\
{[1.33]}\end{array}$ & $\begin{array}{c}1.510 * * \\
{[2.02]}\end{array}$ & $\begin{array}{c}1.933 * * \\
{[2.45]}\end{array}$ & $\begin{array}{l}1.491 \% \\
{[1.93]}\end{array}$ & $\begin{array}{l}1.583 * \\
{[1.93]}\end{array}$ \\
\hline GDP growth (t-1) & $\begin{array}{l}0.005 \\
{[0.40]}\end{array}$ & & & & & & & \\
\hline Population growth (t-1) & & $\begin{array}{l}0.000 \\
{[0.01]}\end{array}$ & & & & & & \\
\hline New state, dummy & & & $\begin{array}{c}-0.269 * * \\
{[2.24]}\end{array}$ & & & & & \\
\hline War, dummy & & & & $\begin{array}{c}0.694 * * \\
{[2.30]}\end{array}$ & & & & \\
\hline Ethnic fractionalization & & & & & $\begin{array}{l}0.268 \\
{[0.44]}\end{array}$ & & & \\
\hline Language fractionalization & & & & & & $\begin{array}{l}-0.834 \\
{[1.62]}\end{array}$ & & \\
\hline Religious fractionalization & & & & & & & $\begin{array}{l}0.092 \\
{[0.17]}\end{array}$ & \\
\hline Opposition fractionalization & & & & & & & & $\begin{array}{l}-0.085 \\
{[0.28]}\end{array}$ \\
\hline Constant & $\begin{array}{c}-9.390 * * * \\
{[4.06]}\end{array}$ & $\begin{array}{c}-7.544 * * * \\
{[3.31]}\end{array}$ & $\begin{array}{c}-5.019 * * \\
{[2.04]}\end{array}$ & $\begin{array}{c}-8.350 * * * \\
{[3.70]}\end{array}$ & $\begin{array}{c}-9.582 * * * \\
{[3.91]}\end{array}$ & $\begin{array}{c}-9.010 * * * \\
{[3.90]}\end{array}$ & $\begin{array}{c}-9.279 * * * \\
{[3.96]}\end{array}$ & $\begin{array}{c}-5.645^{* *} \\
{[2.22]}\end{array}$ \\
\hline Observations & 823 & 826 & 767 & 767 & 826 & 826 & 826 & 717 \\
\hline Number of countries & 63 & 63 & 60 & 60 & 63 & 63 & 63 & 54 \\
\hline Wald test (Prob>chi2) & 0.00 & 0.00 & 0.00 & 0.00 & 0.00 & 0.00 & 0.00 & 0.00 \\
\hline
\end{tabular}

Notes:

The dependent variable is the number of transnational terror events in a particular year and country.

All regressions include a dummy for each year.

Absolute value of $\mathrm{z}$ statistics in brackets.

* significant at $10 \%$; * significant at $5 \%$; ** significant at $1 \%$ 


\section{References}

Abadie, A., 2006, Poverty, Political Freedom, and the Roots of Terrorism, American Economic Review 96, 2: 50-56.

Alesina, A., Easterly, W., Devleeschauwer, A., Kurlat, S. and R. Wacziarg, 2003, Fractionalization, Journal of Economic Growth 8: 155-194.

Becker, G.S., 1968, Crime and Punishment: An Economic Approach, Journal of Political Economy 76: 169-193.

Betz, J., 1996, Verfassungsgebung und Verfassungswirklichkeit in der Dritten Welt, NordSüd Aktuell, 60-64.

Beck, T., Clarke, G., Groff, A., Keefer, P. and P. Walsh, 2001, New tools in comparative political economy: The Database of Political Institutions, World Bank Economic Review 15, 1: 165-176.

Bjørnskov, C., Dreher, A. and J.A.V. Fischer, 2007, On Decentralization and Life Satisfaction, Economics Letters, forthcoming.

Brennan, G. and J.M. Buchanan, 1980, The power to tax. Analytical foundations of a fiscal constitution. Cambridge: Cambridge University Press.

Dorn, D., Kirchgässner, G., Fischer, J.A.V. and A. Sousa-Poza, 2007, Is It Culture or Democracy? The Impact of Democracy and Culture on Happiness. Social Indicators Research, 82(3), pp. 505-526.

Dreher, A., 2006, The Influence of Globalization on Taxes and Social Policy - an Empirical Analysis for OECD Countries, European Journal of Political Economy 22, 1: 179201.

Dreher, A. and M. Gassebner, 2007, Does Political Proximity to the U.S. Cause Terror? Economics Letters, forthcoming.

Dreher, A., Gassebner, M. and L.H.-R. Siemers, 2007, Does Terror Threaten Human Rights? Evidence from Panel Data, KOF Working Paper 156, ETH Zurich.

Dreher, A., Martens, P. and N. Gaston, 2008, Measuring Globalisation - Gauging its Consequences, New York: Springer.

Dreher, A. and J.-E. Sturm, 2006, Do IMF and World Bank Influence Voting in the UN General Assembly? KOF Working Paper 137, ETH Zurich.

Ebel, R.D. and S. Yilmaz, 2002, On the Measurement and Impact of Fiscal Decentralization, World Bank, mimeo.

Enders, W. and T. Sandler, 1995, Terrorism theory and applications. In: Hartley, K., Sandler, T. (Eds.), Handbook of Defense Economics, vol. 1. Elsevier, Amsterdam: 213-249. 
Enders, W. and T. Sandler, 1999, Transnational Terrorism in the post-cold war era, International Studies Quarterly 43, 1: 145-67.

Enders, W. and T. Sandler, 2002, Patterns of transnational terrorism 1970-99: Alternative time series estimates, International Studies Quarterly 46, 2: 145-65.

Enders, W. and T. Sandler, 2005, Transnational Terrorism 1968-2000: Thresholds, Persistence, and Forecasts, Southern Economic Journal 71, 3: 467-482.

Enders, W. and T. Sandler, 2006, Distribution of Transnational Terrorism among Countries by Income Class and Geography after 9/11, International Studies Quarterly 50, 2: 367-394.

Fischer, J.A.V., 2005, Do Institutions of Direct Democracy Tame the Leviathan? Swiss Evidence on the Structure of Expenditure for Public Education, CESifo Working Paper Series No. 1628.

Fisman, R. and R. Gatti, 2002, Decentralization and Corruption: Evidence Across Countries, Journal of Public Economics 83, 3: 325-346.

Freedom House, 2005, Freedom in the World 2005: The Annual Survey of Political Rights and Civil Liberties, Washington, D.C.: Freedom House.

Frey, B.S., 1988, Fighting political terrorism by refusing recognition, Journal of Public Policy 7: $179-188$.

Frey, B.S. and S. Luechinger, 2004, Decentralization as a Disincentive for Terror, European Journal of Political Economy 20, 2: 590-515.

Frey, B.S. and S. Luechinger, 2003a, How to fight terrorism: alternatives to deterrence, Defence and Peace Economics 14: 237-249.

Frey, B.S. and S. Luechinger, 2003b, Measuring Terrorism. Institute for Empirical Research in Economics Working Paper No. 171, University of Zurich.

Frey, B.S., Luechinger, S. and A. Stutzer, 2004, Valuing Public Goods: The Life Satisfaction Approach, CESifo Working Paper No. 1158.

Frey, B.S., Luechinger, S. and A. Stutzer, 2000, Happiness, Economy and Institutions, Economic Journal 110, 466: 918-938.

Frey, B.S., Luechinger, S. and A. Stutzer, 2007, Calculating Tragedy: Assessing the Costs of Terrorism, Journal of Economic Surveys 21, 1: 1-24.

Freytag, A., Krüger, J.J. and F. Schneider, 2006, The Origins of Terrorism. Cross-Country Estimates with Discrete Choice and Count Data Methods, presented at the Public Choice Conference 2007. 
Gallup, J.L. and J.D. Sachs, with A. Mellinger, Geography and Economic Development, CID Working Paper No. 1, March 1999.

Gassebner, M., Jong-A-Pin, R. and J.O. Mierau, 2007a, Terrorism and electoral accountability: One strike, you're out! Economics Letters, forthcoming.

Gassebner, M., Jong-A-Pin, R. and J.O. Mierau, 2007b, Terrorism and Cabinet Duration: An Empirical Analysis, KOF Working Papers 181, ETH Zurich.

Hayek, F.A. von, 1968, Competition as a Discovery Procedure, in: id., New Studies in Philosophy, Politics, Economics and the History of Ideas. London: Routledge: 179190.

Hirschman, A.O., 1970, Exit, Voice and Loyalty. Cambridge, Mass.

Keman, H., 2000, Federalism and policy performance. A conceptual and empirical inquiry. In U. Wachendorfer-Schmidt (Ed.), Federalism and political performance, London: Routledge.

Kessing, S.G., Konrad, K.A. and C. Kotsogiannis, 2006, FDI and the dark side of decentralization, Economic Policy 22, 49: 5-70.

Kotsogiannis, C. and R. Schwager, 2005, On the Incentives to Experiment in Federations, mimeo.

Krueger, A.B. and J. Malečková, 2003, Education, Poverty and Terrorism: Is there a Causal Connection? Journal of Economic Perspectives 17, 4: 119-144.

Li, Q., 2005, Does Democracy Promote or Reduce Transnational Terrorist Incidents? Journal of Conflict Resolution 49, 2: 278-297.

Li, Q. and D. Schaub, 2004, Economic globalization and transnational terrorist incidents: A pooled time series analysis, Journal of Conflict Resolution 48, 2: 230-258.

Lichbach, M.I., 1987, Deterrence or escalation? The puzzle of aggregate studies of repression and dissent, Journal of Conflict Resolution 31: 266-297.

Lijphart, A., 1977, Democracy in Plural Societies, New Haven: Yale University Press.

Niskanen, W.A., 1971, Bureaucracy and Representative Government. Chicago: Chicago University Press.

Obinger, H., Leibfried, S. and F.G. Castles, 2005, Introduction: Federalism and the welfare state. In: Obinger, H., Leibfried, S. and F.G. Castles (eds.), Federalism and the Welfare State: New World and European Experiences, Cambridge, Cambridge University Press.

Piazza, J.A., 2006, Rooted in poverty? Terrorism, poor economic development, and social cleavages, Terrorism and Political Violence 18, 1: 159-177. 
Prud'homme, R., 1995, On the Dangers of Decentralization, The World Bank Research Observer, August: 201-210.

Riker, W.H., 1964, Federalism: Origin, operation, significance. Boston: Little Brown.

Rose-Ackerman, S., 1980, Risk taking and reelection: Does federalism promote innovation? Journal of Legal Studies 9: 593-612.

Sandler, T., 1995, On the relationship between democracy and terrorism, Terrorism and Political Violence 4, 4: 14-25.

Sandler, T. and W. Enders, 2004, An economic perspective on transnational terrorism, European Journal of Political Economy 20, 2: 301-316.

Schnellenbach, J., 2006, Appeasing Nihilists? Some Economic Thoughts on Reducing Terrorist Activity, Public Choice 127, 3: 301-313.

Sewell, D., 1996, The Dangers of Decentralization, According to Prud'homme: Some Further Aspects, The World Bank Research Observer, February: 143-150.

Staiger, D., and J.H. Stock, 1997, Instrumental Variables Regression With Weak Instruments, Econometrica 65: 557-586.

Strumpf, K.S., 2002, Does government decentralization increase policy innovation? Journal of Public Economic Theory 4: 207-243.

Stutzer, A., 1999, Demokratieindizes für die Kantone der Schweiz, IEW Working Paper No 23, University of Zurich.

Thacker, S.C., 1999, The high politics of IMF lending, World Politics 52, 1: 38-75.

Tiebout, C.M., 1961, An Economic Theory of Fiscal Decentralization, in: National Bureau Of Economic Research (Ed.), Public Finances: Needs, Sources and Utilization.

Treisman, D., 2000, Decentralization and the quality of government, Working paper, Department of Political Science, University of California, Los Angeles.

Voeten, E., 2004, Documenting Votes in the UN General Assembly, The George Washington University (http://home.gwu.edu/ voeten/UNVoting.htm).

Wilkinson, P., 2002, Terrorism Versus Democracy: The Liberal State Response. Frank Cass, London.

World Bank, 2005, A better investment climate for everyone, World Development Report 2005, World Bank.

World Bank, 2006, World Development Indicators, CD-Rom, Washington, DC. 


\section{Appendix A: Descriptions and sources}

\begin{tabular}{|c|c|}
\hline Variable & Definition \\
\hline Number of terror events & $\begin{array}{l}\text { Number of transnational terror events for each country and year, } \\
\text { defined as "violence, or the threat of violence, calculated to create an } \\
\text { atmosphere of fear and alarm." }\end{array}$ \\
\hline Fiscal decentralization & $\begin{array}{l}\text { Total expenditure of sub-national government tiers divided by total } \\
\text { spending by all levels of government. }\end{array}$ \\
\hline Political autonomy & $\begin{array}{l}\text { Dichotomous indicator of autonomy of second tier governments that } \\
\text { takes on the value of one if "subnational legislatures have autonomy } \\
\text { in certain specified areas - i.e. constitutional authority to legislate - } \\
\text { not explicitly subject to central laws." }\end{array}$ \\
\hline (log) GDP per capita & $\begin{array}{l}\text { Gross domestic product divided by midyear population. Data are in } \\
\text { constant U.S. dollars. }\end{array}$ \\
\hline (log) Population & $\begin{array}{l}\text { Total population is based on the de facto definition of population, } \\
\text { which counts all residents regardless of legal status or citizenship, } \\
\text { except for refugees not permanently settled in the country of asylum. }\end{array}$ \\
\hline Political freedom & $\begin{array}{l}\text { Average value of political rights and civil liberties, ranging from }-7 \text { to } \\
-1 \text {, where higher values reflect greater freedom. }\end{array}$ \\
\hline Political freedom, change & $\begin{array}{l}\text { Yearly change in index ranging from } 1 \text { to } 7 \text {, where higher values } \\
\text { reflect greater freedom. }\end{array}$ \\
\hline Government fractionalization & $\begin{array}{l}\text { Probability that two deputies picked at random from among the } \\
\text { government parties will be of different parties( low(0)-high(1)). }\end{array}$ \\
\hline Voting with U.S. & $\begin{array}{l}\text { Votes in agreement with the US are coded as } 1 \text {, votes in disagreement } \\
\text { as } 0 \text {, and abstentions or absences as } 0.5 \text {. The resulting numbers are } \\
\text { then divided by the total number of votes in each country and year. }\end{array}$ \\
\hline GDP growth & $\begin{array}{l}\text { Annual percentage growth rate of GDP at market prices based on } \\
\text { constant local currency. Aggregates are based on constant } 2000 \text { U.S. } \\
\text { dollars. }\end{array}$ \\
\hline Population growth & $\begin{array}{l}\text { Annual population growth rate, based on the de facto definition of } \\
\text { population. }\end{array}$ \\
\hline New state, dummy & $\begin{array}{l}\text { The timing of national independence ( } 0 \text { if before } 1914 ; 1 \text { if between } \\
1914 \text { and } 1945 ; 2 \text { if between } 1946 \text { and } 1989 ; \text { and } 3 \text { if after 1989). }\end{array}$ \\
\hline War, dummy & Dummy for countries that had external war over the period $1960-85$. \\
\hline Ethnic fractionalization & $\begin{array}{l}\text { Fractionalization }_{\mathrm{j}}=,_{1}-\sum_{i=}^{n} s_{i j}^{2} \\
\text { with } \mathrm{s}_{\mathrm{ij}} \text { being the share } \text { of }_{\text {froup } \mathrm{i} \text { in country } \mathrm{j}}\end{array}$ \\
\hline Language fractionalization & $\begin{array}{l}\text { Fractionalization }{ }_{\mathrm{j}}=, 1-\sum_{i=1}^{n} s_{i j}^{2} \\
\text { with } \mathrm{s}_{\mathrm{ij}} \text { being the share of group } \mathrm{i} \text { in country } \mathrm{j} \text {. }\end{array}$ \\
\hline Religious fractionalization & $\begin{array}{l}\text { Fractionalization }{ }_{\mathrm{j}}=, 1-\sum_{i=1}^{n} s_{i j}^{2} \\
\text { with } \mathrm{s}_{\mathrm{ij}} \text { being the share of group } \mathrm{i} \text { in country } \mathrm{j} \text {. }\end{array}$ \\
\hline Opposition fractionalization & $\begin{array}{l}\text { Probability that two deputies picked at random from among the } \\
\text { opposition parties will be of different parties( low(0)-high(1)). }\end{array}$ \\
\hline
\end{tabular}

\begin{tabular}{|c|}
\hline Source \\
\hline \multirow{2}{*}{$\begin{array}{l}\text { MIPT Terrorism } \\
\text { Knowledge Base }\end{array}$} \\
\hline \\
\hline IMF's Government \\
\hline Finance Statistics \\
\hline Treisman (2002) \\
\hline World Bank (2006) \\
\hline World Bank (2006) \\
\hline Freedom House (2005) \\
\hline Freedom House (2005) \\
\hline Beck et al. (2001) \\
\hline Dreher and Sturm (2006) \\
\hline World Bank (2006) \\
\hline World Bank (2006) \\
\hline Gallup et al. (2001) \\
\hline Gallup et al. (2001) \\
\hline Alesina et al. (2003) \\
\hline Alesina et al. (2003) \\
\hline Alesina et al. (2003) \\
\hline Beck et al. (2001) \\
\hline
\end{tabular}




\section{Appendix B: Descriptive Statistics}

\begin{tabular}{|c|c|c|c|c|}
\hline Variable & Mean & Std. Dev. & Min & Max \\
\hline Number of terror events & 1.70 & 4.59 & 0.00 & 50.00 \\
\hline Fiscal decentralization & 20.84 & 13.48 & 1.45 & 55.62 \\
\hline Political autonomy & 0.15 & 0.36 & 0.00 & 1.00 \\
\hline$(\log )$ GDP per capita & 7.51 & 1.53 & 4.31 & 10.64 \\
\hline (log) Population & 15.95 & 1.61 & 12.29 & 20.95 \\
\hline Political freedom & -3.66 & 1.97 & -7.00 & -1.00 \\
\hline Political freedom, change & 0.03 & 0.46 & -4.00 & 3.50 \\
\hline Government fractionalization & 0.20 & 0.29 & 0.00 & 1.00 \\
\hline Voting with U.S. & 0.30 & 0.15 & 0.06 & 0.84 \\
\hline GDP growth & 3.08 & 5.79 & -51.03 & 38.20 \\
\hline Population growth & 1.73 & 1.44 & -16.55 & 18.71 \\
\hline New state, dummy & 1.25 & 1.03 & 0.00 & 3.00 \\
\hline War, dummy & 0.14 & 0.35 & 0.00 & 1.00 \\
\hline Ethnic fractionalization & 0.43 & 0.26 & 0.00 & 0.93 \\
\hline Language fractionalization & 0.39 & 0.29 & 0.00 & 0.92 \\
\hline Religious fractionalization & 0.41 & 0.25 & 0.00 & 0.86 \\
\hline Opposition fractionalization & 0.49 & 0.29 & 0.00 & 1.00 \\
\hline
\end{tabular}

Note: Statistics are based on the estimation sample of Table 1, column 2. 
Appendix C: Average number of terror events per year

\begin{tabular}{|c|c|c|}
\hline year & terror events & severe terror events \\
\hline 1976 & 1.53 & 1.23 \\
\hline 1977 & 1.59 & 1.33 \\
\hline 1978 & 1.46 & 1.35 \\
\hline 1979 & 1.97 & 1.88 \\
\hline 1980 & 1.05 & 0.88 \\
\hline 1981 & 1.07 & 0.91 \\
\hline 1982 & 1.50 & 1.34 \\
\hline 1983 & 1.67 & 1.39 \\
\hline 1984 & 2.28 & 1.63 \\
\hline 1985 & 2.93 & 2.64 \\
\hline 1986 & 2.41 & 2.11 \\
\hline 1987 & 2.61 & 2.35 \\
\hline 1988 & 2.24 & 2.04 \\
\hline 1989 & 2.25 & 1.84 \\
\hline 1990 & 2.68 & 2.20 \\
\hline 1991 & 3.47 & 2.69 \\
\hline 1992 & 1.86 & 1.59 \\
\hline 1993 & 1.79 & 1.56 \\
\hline 1994 & 1.76 & 1.38 \\
\hline 1995 & 1.03 & 0.86 \\
\hline 1996 & 1.09 & 0.94 \\
\hline 1997 & 0.79 & 0.55 \\
\hline 1998 & 1.03 & 0.87 \\
\hline 1999 & 0.82 & 0.67 \\
\hline 2000 & 0.76 & 0.70 \\
\hline
\end{tabular}

Note: Numbers are based on the estimation sample of Table 1, column 2. 